DOI: http://doi.org/10.21698/simi.2017.0041

\title{
GLOBALIZATION AS EMPOWERMENT TOWARDS ECOLOGY
}

Florina Bran, Mariana Iovitu, Dumitru-Alexandru Bodislav

The Bucharest University of Economic Studies, 2-10 Caderea Bastiliei, Bucharest, Romania, florinabran@yahoo.com

\begin{abstract}
This paper tries to underline the need to empower ecology as part of globalization process and globalization as key ignitor of eco-economics. In these days of economic distress, we need to induce the idea of social ecological responsibility to help protect our environment and natural resources towards prolonging the life span of what we can procure from our Earth's resources and also keep something for future generations.
\end{abstract}

Keywords: ecology, economics, globalization, natural resources

\section{Introduction}

In the 21 st century, the phenomenon of inevitable globalization is being discussed, but the opinions are also the opposite. After all, what does that mean? Is it a concept that can be adjusted or a disastrous reality? It is a phenomenon that grows as a result of the development of the new technology and its rapidity as well as the information that reaches a stunning speed from one corner to the other on Earth. It is also the consequence of cruel and careless human facts about the environment, social, economic and especially political. These are just a few of our dilemmas and we are trying to find a more plausible answer.

Starting from the premise of this quote, we realize that this process, named in the last century, "globalization" has its origins right from the beginning of civilization with the moment when the man in his desire to know more and to have as much migration to the lands Richer, in full progress.

The globalization that process level is not a new phenomenon in human experience, but the extent and the contemporary coverage of the phenomenon are unprecedented. If we look at today, the US economic crisis has left no other country unaffected because the trading systems are very dependent on each other (Bran et al. 2014).

As globalization is a complex set of processes that affect virtually every aspect of our everyday life - art, culture, economy, politics, immigration, climate, health - studies of globalization show us without a host of humanistic, social perspectives and scientific knowledge of the forms that globalization takes, the forces that shape them, their historical origins and their impact on all aspects of the lives of individuals and communities.

Without doubting this, the 18th and 19th centuries represented and now represent the most dynamic and dense periods in close connection with the unfolding of historical, social contradictory and complex facts but equally dramatic by the consequences of the processes and phenomena unfolding in the plan Spiritual, political-military, economic and social, which have led to the spread of globalization (Bran et al. 2012). We can assert that it is the "Extreme Century" in which mankind has 


\section{INTERNATIONAL SYMPOSIUM "THE ENVIRONMENT AND THE INDUSTRY", SIMI 2017, PROCEEDINGS BOOK}

experienced the most spectacular evolutions, from nothing to almost everything, managing both to "stop time in place" and to know the highest level of economic and cultural development of civilizations actually felt at the very high threshold today. But it is also the century in which hundreds of millions of people have been victims of wars, revolutions in different fields, and from different ideologies, whether religious, ethnic or political.

\section{Results and Discussion}

\section{Globalization - 360}

Globalization is a very common concept used to characterize the current state of the economy at a global level, but it is understood differently by every man because of the perception of the events happening in our lives. Some people perceive it as a complex and complete uniformity, others, on the contrary, that a diversification in the sense of a river of proportions, based on the observance of common principles imposed.

This is presented as a phenomenon specific to the end of the century and the millennium, globalization - or at least some of its dimensions is based on a long history. Under this latter aspect, globalization is the almost natural consequence of the increasingly accelerated course imprinted on history, the first Industrial Revolution.

What distinguishes the contemporary phenomenon of globalization from the previous integration processes since its first appearance is: - scale (formerly regional, current world); - the pace of slow but sure changes at the beginning, and now very fast for 40-50 years now, supporting more technological progress than before, with immediate and irreversible impact on the conditions of everyday life.

With the advent of the Industrial Revolution, globalization is as strong as possible with the discovery of new territories and migratory flows. But the most exciting is the synchronized development with the technological progression by which manual work has been replaced by machinery. In this mechanized process, the worker, that is, the most important actor in the globalization, has the role of supervising, regulating and feeding the machine and controlling the quality. The industrial revolution had the effect of increasing production, improving the quality of life, and making man aware that he can hold more capital, more power, which made him sacrifice himself to live a life full of reward.

It is only after the end of the Second World War that we can consider the extraordinary momentum of globalization; When the process has become a widespread phenomenon (or when the world has really become aware of it), an alarming and extremely satisfying growth in rich countries (Bran et al. 2009). From now on, we can think of globalization as a union among nations that aims to reorganize national borders and transpose them into a single one through which certain transfers can be made: a workforce called "brain theft" or intellectual theft, then leveling. Taxes unfortunately for the less developed countries that cannot keep pace with the opulent states, the establishment of standard rules that do not have a very effective impact in poor countries. Lack of capital results in environmental disintegration, falling population, increased mortality.

The chaos we face today results from the fact that, starting from the development of the most important economic and technological plans, whose origins come mainly 


\section{INTERNATIONAL SYMPOSIUM "THE ENVIRONMENT AND THE INDUSTRY", SIMI 2017, PROCEEDINGS BOOK}

from the United States of America, makes the potential differences of all countries to create a so-called Racing in profit and power.

The declared objectives of globalization are concretized in one: a world governance system and a world society with universal rules and thinking in unison. But there is only one question. Who is the benefit of this transformation of all national governments into a single world in fact? Rich countries that allow themselves to go through the transition or poor countries that have to go in order to go through the transitions? This paradigm of today's global society that we will discuss in the continuation of this work with solid and grounded arguments.

\section{Globalization - a disruptive factor for the environment}

Globalization is the process by which all peoples and communities "are affiliated" to experience a more and more common, yet similar, economic, social and cultural environment more or less similar. By definition, the process affects everyone in the whole world, regardless of our will or not.

Globalization, which is a word partly synonymous with the growth of trade all over the world, has favoured large-scale production, trade and consumption of unprecedented material goods unprecedented 100 years ago. This has weighed the footprint of human activities around the world, protecting her from hard work. Although it is still difficult to assess the impact of globalization on the environment, it is quite obvious to some people, but in some areas we can argue with solid and tragically real arguments that this phenomenon affects all areas by treating all such things unfortunately

Questions that have linked globalization to the environment have grown largely as a result of extraordinary economic growth in some parts of the world, and in other parts of the world it has been steadily declining, but globalization has meant a very important concept change on how we each think of the environment. Many of us today see environmental issues as being of international interest, not exclusively national interest, such as the protection of the rivers that become the tributaries of the seas and the end of the planetary ocean and, last but not least, the pollution atmosphere of each state Chosen from those with high idle share. The environment is considered to be "patrimony" and the problems connected with it are increasingly the object of international bodies' efforts due to their cross-border effects and the impossibility that only one or some of the particularly rich nations can solve these big dilemmas on their own.

Climate change is one of the main environmental problems, perhaps all the more worrying, because it is impossible to predict exactly how it will develop and what the consequences will be if it is negative. Its causes, however, are known. Climate change comes largely from the greenhouse effect - that is, the excessive retention of solar energy in the atmosphere due to the accumulation of certain gases, especially $\mathrm{CO} 2$. The main sources of $\mathrm{CO} 2$ emissions are industrial production, transport and, more indirectly, deforestation. These three human activities exist independently of globalization, but their stunning and accelerated development during the 20th century is partly related to globalization.

\section{Globalization, the promoter of mass deforestation}

Deforestation is an indirect but probably the most serious and significant cause of the greenhouse effect, landslides, and many other issues that are now threatening the 


\section{INTERNATIONAL SYMPOSIUM "THE ENVIRONMENT AND THE INDUSTRY", SIMI 2017, PROCEEDINGS BOOK}

Earth. Clearing reduces the volume of $\mathrm{CO}_{2}$ that plants convert to oxygen, this translates into an equivalent increase in the volume of $\mathrm{CO}_{2}$ in the atmosphere and thus adds to the greenhouse effect. And the burning of the removed wood releases large amounts of $\mathrm{CO}_{2}$.

Over the past 30 years, globalization has brought about rapid and deep changes in countries around the world, more or less. Generally, there has been a tendency to decentralize the government and reduce the role it plays in the everyday life of its citizens. In countries under development, this "change" has major implications for forests.

Whether it is driven by a market economy (consumption) or imposed by a "command" economy, forest management is usually the responsibility of forestry services in the public domain. In order to stop illicit mass deforestation, public bodies have decided to privatize these forest lands under the leadership of private firms, NGOs, etc. But this decision seems to have been and is in vain if we look around thousands of hectares of raging forests.

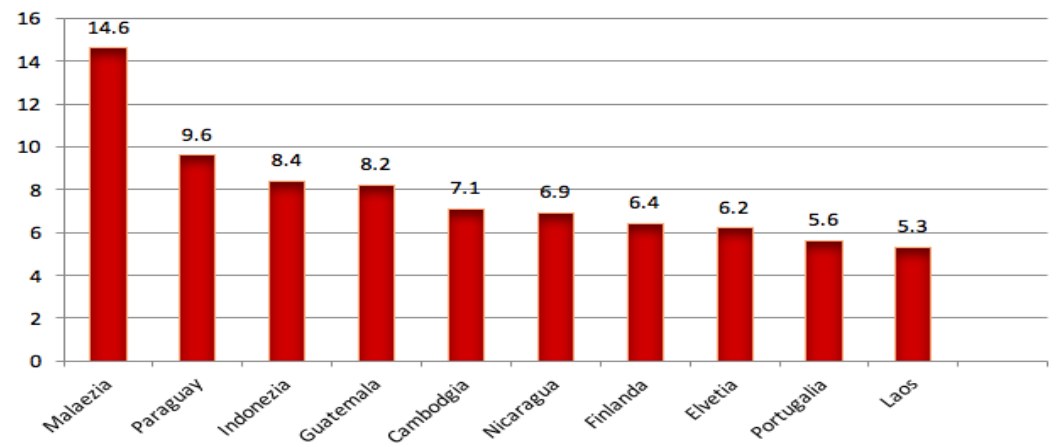

Figure 1. Top for illegal deforestation worldwide

Source: data filtered by the author using www.news.mongabay.com

On the chart we have the countries with the highest percentage of illegal deforestation in the world in descending order.

The total loss of forest in Malaysia amounted to 14.4 percent of the country's wooded cover from 2000 to 2014 . The loss is 47,278 square kilometers (18,244 square miles), a larger area than Denmark.

As a critical promoter of globalization, transport systems have, along with international trade, multiplied emissions from road transport (mainly cars and trucks), which are, of course, very high, even more so within the national borders of developing countries in particular economic. As we know, the opening of regional areas (such as the total abolition of border controls between EU countries) has greatly propelled transport of goods by road. Despite recent alternatives, truck transport by train for part of the journey, trans-national road transport is an important source of $\mathrm{CO}_{2}$ emissions. 


\section{INTERNATIONAL SYMPOSIUM "THE ENVIRONMENT AND THE INDUSTRY", SIMI 2017, PROCEEDINGS BOOK}

Globalization $=$ greenhouse effect.

The greenhouse effect increases the Earth's temperature by capturing the heat in the atmosphere. This keeps Earth's temperature higher than if the direct sunlight was the only source of light. When it reaches the surface of the Earth, part of it is absorbed, that is, that which heats the soil, then the rest riches back into space in the form of heat. The greenhouse gases that are in the atmosphere absorb and then redirect some of this heat back to Earth.

The greenhouse effect is a major factor in keeping our planet warm. In fact, without the greenhouse effect, the average global Earth's temperature would be much lower and life on Earth as we know it would not be possible.

Globalization "indirectly" promotes $\mathrm{CO}_{2}$ emissions related to industrial activity.

While the Industrial Revolution was a vector of globalization, growth in cross-border trade and investment in its turn stimulated industrial activity. This is often a major source of GHG emissions, as in the case of electricity production, which still involves coal burning, oil and its derivatives. The intensification of globalization has then accentuated the greenhouse effect and global warming (global warming is one of the undesirable effects that would appear to be a major problem of humanity that is neglected or given to a deliberate second plan.

For decades, developed countries, pioneers of global industrialization, have been the world's largest polluters, responsible for most of GHG emissions. Today, the United States is responsible for about $20 \%$ of global emissions.

According to International Energy Agency (IEA) statements, in 2016 carbon dioxide emissions stagnated for the third consecutive year, and curiosity is that the economy globally has increased. In China and the US they have fallen, and in Europe they have stagnated.

According to the agency, the largest decrease was in the US (-3\%), i.e. 160 million tons of carbon dioxide $\left(\mathrm{CO}_{2}\right)$ less than in the previous years, while the economy grew by $1.6 \%$.

EU carbon dioxide emissions stagnated in 2016. This happened when demand for gas increased by $8 \%$ and demand for coal fell by $10 \%$. Renewable energy has played a significant role, but one quite small. Researchers say the decline was driven by a sharp increase in shale gas supplies and renewable energy sources that replaced coal.

In China, carbon dioxide emissions dropped by $1 \%$ in 2016. At a time when demand for coal fell, the economy grew by $6.7 \%$. Experts say that the share of renewable energy, nuclear energy and natural gas has contributed to this (Bodislav 2012).

\section{Globalization and behavior of multinational companies to the environment}

A multinational company actually carries out an enterprise operating in several states, but it is managed from a single country. Typically, any company or group that earns a quarter of its revenue from operations outside its home country is considered a multinational corporation.

There are four categories of multinational corporations:

1. Multinational corporation, decentralized with a strong presence to the country of origin;

2. A global, centralized corporation that gains a centralized production cost advantage whenever it is cheaper;

3. International company based on R \& D and its HQ's practices; 


\section{INTERNATIONAL SYMPOSIUM "THE ENVIRONMENT AND THE INDUSTRY", SIMI 2017, PROCEEDINGS BOOK}

4. A transnational enterprise that combines the three previous approaches. Industrial corporations are abundant in terms of technology innovation and investment capital in increasing their production. In the context of globalization, privatization and market liberalization, they are considered to be one of the most important factors in shaping the future of the world. However, these factors have brought not only an economic growth but also a negative effect on the environment (Bodislav 2015).

In an attempt to reduce costs, many multinational corporations have expanded their polluting export activities through subsidiaries established in less developed countries. Environment pollution does not necessarily have to cross a country's borders as a substance, it can also cross the border by a decision taken in a state that leads to environmental consequences in another. Otherwise, the environmental degradation resulting from the subsidiary's activities can often be traced back to the parent company's regulatory orders. Importantly, because multinationals are large contributors to the world economy, they enjoy significant political power on the international stage. The predominant position of these corporate giants is not equally balanced with that of victims when they seek to make multinational responsibility for environmental damage. Most often, the cost of production is required to combat by introducing non-environmentally friendly manufacturing processes and consumables used in production, which slowly, but systematically put their mark on the environment.

Ironically, all the elements of the environment still offer us the opportunity to walk clean streets and breathe fresh air, despite the fact that pollutants are rapidly multiplying every day. From multinational companies, road traffic and people who deliberately deforest and pollute, we all have our part to blame for endangering.

\section{Conclusions}

The phenomenon of globalization determines the extraordinary development of already overdeveloped economies; Developing economies are losing momentum and declining. States lose their national identity, especially the middle and small, and become parts of the regions with a strong reputation due to the regress of their national economies.

Everyday life in Europe and America, these being the continents with a predominantly high rate of development, influences the natality rate, causing the population to straighten their efforts towards economic development and career not to procreation. The global climate will suffer very much in the next 50-100 years. The effect of the greenhouse gives rise to extremely hot summers, droughts with temperatures above 40 degrees, melting glaciers and polar fauna and mountain areas.

Measures to reduce population will have a devastating effect in developed areas, while in poor areas will have no effect and will continue the alarming rise of the population. Deindustrialization measures will increase until most state-owned institutions that make a significant contribution to GDP will be privatized or bankrupt.

\section{References}

Bodislav, DA 2012, 'Sustainable economic growth - the innovative value created through knowledge collaboration', Proceedings of International Conference on Knowledge-Based Organization, "Nicolae Bălcescu" Army Academy, Sibiu, pp. 50-55. 
Bodislav, DA 2015, 'The impact of privatisation on regulated energy markets: a Great Britain's case study in industrial ecology', Progress in Industrial Ecology, vol. 9, no. 1, pp. 13-18.

Bran, F, Bodislav, DA, Radulescu CV, Ioan I 2014, 'Corporate governance intervention for a sustainable socio-economic model', Revista de Cercetare și Intervenție Socială, vol. 46, pp. 216-226.

Bran, F, Ioan, I 2009, Globalizarea și mediul, Universitara Publishing House, Bucharest.

Bran, F, Manea, I, Ioan, I, Radulescu, CV 2012, Globalizarea: manifestări și reacții, Economica Publishing House, Bucharest. 